\title{
THE POLITICISATION OF ISLAM IN MALAYSIA AND ITS OPPONENTS
}

\author{
Alexander Wain*
}

\begin{abstract}
This article profiles four prominent detractors of Islam's politicisation in contemporary Malaysia. While much ink has been spilt profiling the promulgators of politicised Islam, whether in Malaysia or elsewhere, comparatively little has been written about those who oppose it. This article is a modest attempt to rectify that deficiency. It begins, however, with a brief history of that politicisation process as it has occurred in Malaysia, with particular reference to Parti Islam Se-Malaysia (PAS) and Angkatan Belia Islam Malaysia (ABIM). This brief overview traces Malaysia's unique form of politicised Islam to late twentieth-century intercommunal tensions driven by Malay poverty and cultural anxiety. These enabled long-standing ethno-religious associations to facilitate a blending of Islamist ideology with issues surrounding Malay rights. It is within this context that we then examine the social and educational backgrounds, principal publications, records of activism, and ideological positions of four prominent critics of Malaysian Islam's politicisation, namely: Chandra Muzaffar, Zainah Anwar, Marina Mahathir, and Siti Kasim. The article concludes that all four figures differ from their counterparts in PAS and ABIM by possessing Western-orientated backgrounds, a long-standing dedication to multiculturalism, and a desire to orientate their work around human rightsbased issues. The article concludes by suggesting how (or if) these detractors can impact the future direction of Malaysian politics.
\end{abstract}

Keywords: Islam, Malaysian politics, PAS, ABIM, Chandra Muzaffar, Zainah Anwar, Marina Mahathir, Siti Kasim

\section{Introduction}

This article presents short contextualised biographies of four prominent opponents of Islam's politicisation in contemporary Malaysia. While much ink has been spilt profiling the promulgators of politicised Islam, whether in Malaysia or elsewhere, comparatively little has been written about those who oppose it. This article is a modest attempt to rectify that deficiency. It begins, however, with an overview of how Islam became established within modern Malaysia's political landscape; concentrating on the country's political heartland, the 
Malay Peninsula, the article traces how late twentieth-century intercommunal tensions driven by Malay economic and cultural disenfranchisement enabled long-standing ethno-religious associations to facilitate a blending of Islamist ideology with issues surrounding Malay rights. Focusing on Malaysia's most prominent Islamist organisations, Parti Islam Se-Malaysia (PAS, 'PanMalaysian Islamic Party') and Angkatan Belia Islam Malaysia (ABIM, 'Muslim Youth Movement of Malaysia'), who together helped create and normalise contemporary Malaysia's tradition of politicised Islam, the article describes how both organisations rooted their political agendas in a postcolonial concern for preserving indigenous racial and religious identity. Against this backdrop, the article profiles our four opponents: Chandra Muzaffar, Zainah Anwar, Marina Mahathir, and Siti Kasim. Characterised by a willingness to speak truth to power, these figures stand apart from their peers as significant social influencers capable of attracting largescale media attention. Here we briefly summarise their social and educational backgrounds, principal publications, records of activism, and ideological positions, consistently contrasting these biographical pointers with the specific features of Islam's politicisation in Malaysia. Ultimately, we conclude that all four opponents differ from the promulgators of politicised Islam with regards to their Western-orientated backgrounds, dedication to multiculturalism, and frequent appeals to human rights-based discourses. We conclude by suggesting how (or if) our subjects can impact the future direction of Malaysian politics.

\section{Islam and the Political Landscape in Malaysia}

Islam was first absorbed into the political landscape of what is now Malaysia around six centuries ago. In c.1412, the (either first or second) Hindu-Buddhist ruler of Melaka embraced Islam, changed his name to (Megat) Iskandar Shah, and began using culturally Islamic terminology to justify his (previously divine) right to rule. Taking popular pre-Islamic Persian conceptions of the ruler as a "Shadow of God" on earth (prevalent among Muslims since the Abbasid period) and fusing them with Sufism's Perfect Man (al-insan al-kamil, representing Muhammad), Iskandar and his successors were able to craft a mystically derived, semi-divine status for themselves, even appropriating an Arabic term to describe it: daulat. ${ }^{1}$

While this early (rather syncretic) manifestation of Islam in the political sphere has persisted, to a greater or lesser degree, into the present, more modern conceptions of what M. Laffan terms an "organic link" between Islamic religious praxis and state identity did not emerge in what is now Malaysia until the late 
nineteenth century. Over that period, a group of reformist intellectuals called kaum muda (young generation), based in the Straits Settlements but with roots in the Minangkabau highlands of Sumatra, ${ }^{2}$ began appropriating the Cairene reformist discourse of Muhammad 'Abduh (d. 1905) and Rashid Rida (d. 1936). Arguing that a failure to maintain the true principles of Islam had allowed European civilisation to surpass the Islamic world, culminating in the latter's colonisation, the kaum muda favoured rigorous social modernisation in tune with modern scientific and philosophical principles. They also sought to revive Muslim consciousness by restoring indigenous sovereignty, envisioning an Islamic state headed by socially active 'ulama'. Although infused with Islamic values, this state would be based on modern constitutional parliamentary democracy. ${ }^{3}$

As the twentieth century unfolded, this reformist ideology laid the groundwork for a series of Islamically orientated social and political movements right across the Malay Peninsula. ${ }^{4}$ After independence in 1957, these movements steadily gained in popularity; by the 1970s, two in particular, Parti Islam Se-Malaysia (PAS) and Angkatan Belia Islam Malaysia (ABIM), had garnered sufficient support to begin reshaping, both directly and indirectly, Malaysia's internal political trajectory, notably by inducing a period of intense government-led Islamisation. As we shall see, each of our four opponents to Islam's politicisation in Malaysia emerged from the liberal secular backlash to this Islamisation project. For the sake of accurately mapping their intellectual trajectory, therefore, it behoves us to briefly describe the background of that project, including the role PAS and ABIM played therein.

Unlike Islamist organisations elsewhere in the Muslim world, PAS and ABIM did not evolve out of an overwhelmingly Muslim settling, but within an intrinsically multireligious environment: although predominantly Muslim (61.3 per cent), Malaysia is also home to substantial Buddhist (19.8 per cent), Christian ( 9.2 per cent), and Hindu (6.3 per cent) populations. ${ }^{5}$ This religious plurality both reflects and interlinks with a similar degree of ethnic diversity: 68.8 per cent Bumiputera (including Malays), 23.2 per cent Chinese, and 7 per cent Indian. In the political sphere, this diversity has traditionally translated into a collection of political organisations defined by both ethnicity and religion, where Malay identity is linked to Islam, Chinese identity to Buddhism, and so on. ${ }^{6}$ Within this context, both PAS and ABIM have tended to meld (even subordinate) explicitly Islamist agendas to issues surrounding the Malays. PAS, for example, although unequivocally Islamist since its inception in 1951, has habitually situated that commitment within a broader postcolonial narrative framing Malay identity as a means of resisting imperialism. Thus, defining Islamic 'authenticity' in terms of state-level adherence to shariah (that is, the creation of an Islamic State headed 
by 'ulama'), PAS has traditionally fused a frequently plasticine notion of how that adherence can be achieved with a desire to establish Malay cultural and political centrality within Malaysia in direct opposition to foreign (including Chinese) hegemonies. ${ }^{8}$

Similarly, although often ideologically linked to international and strictly Islamist organisations like Egypt's Ikhwanul Muslimun ('Muslim Brotherhood') and South Asia's Jamaat-e-Islami ('Islamic Congress'), ${ }^{9}$ ABIM has also situated Islam within a much broader Malay rights discourse. Founded in August 1971 by Malay Muslim university students affiliated with Persatuan Bahasa Melayu Universiti Malaya (PBMUM, 'University of Malaya Malay Language Society') and Persatuan Kebangsaan Pelajar-Pelajar Islam Malaysia (PKPIM, 'National Union of Malaysian Muslim Students'), ${ }^{10}$ ABIM's long-term ideological stance was defined early on by its most prominent leader to date, Anwar Ibrahim (cofounder and president, 1974-1982). Significantly, therefore, Anwar first entered political activism not as an idealistic young Muslim seeking to create an Islamic State, but as a vocal and charismatic champion of Malay rights. Speaking during an interview in 1987, Anwar described how he co-founded ABIM not to establish an Islamic State, but to organise young Malay voices in opposition to the government's perceived neglect of Malay rights:

The leaders were condemning corruption, but they were enriching themselves. They talked about Malay nationalism but they were alienated from the Malay masses. They were obsessed with the west. They were too accommodating to non-Malay sentiments...We were impatient and angry about the plight of the Malays, their education, rural development, rural health...11

Disgusted by "the utter failure of the Malay leadership to address issues of poverty [and] landlessness" among the Malays, ${ }^{12}$ Anwar moulded ABIM into a movement dedicated to highlighting these issues; in 1974 he was even detained by the government for 2 years after leading protests in support of poor Malay farmers from Baling, Kedah, who were being forced from their land by state authorities with only minimal compensation. ${ }^{13}$ But crucially, Anwar was also able to draw upon the aforementioned Malay-Islam linkage to successfully transform racial issues like these into Islamic ones. For both Anwar and ABIM, the promotion of Islam and Islamic issues was not therefore an end in itself, but a means of asserting Malay rights; the more central Islam was within society, the more important were the Malays. Unlike PAS's top-down approach (an Islamic State founded by 'ulama'), however, ABIM sought to achieve this centrality by encouraging an individual-level return to Qur'an and Sunnah. This would raise 
Muslim consciousness among primarily secular-educated urban Malays with the intention of suffusing modern Malaysian society with Islamic values, essentially Islamising (and Malay-ising) it from the ground up.

In 1982, after 8 years as ABIM president, Anwar Ibrahim surprised his allies by joining the United Malays National Organisation (UMNO), a constituent part of the ruling Barisan Nasional (BN, 'National Front') coalition, then under the control of Mahathir Mohamed (Malaysia's fourth and seventh prime minister). With Malaysia's middle class quickly becoming engulfed in a global tide of Islamic resurgence, Mahathir sought to co-opt ABIM's Islamisation agenda in order to undercut support for PAS among Malay voters. He therefore allowed Anwar (Deputy PM by 1993) to bring his bottom-up, racialised Islamic agenda to government, where it informed an Islamisation project that saw Islam-based social and educational institutions emerge across the country and government programmes become infused with Islamic values. ${ }^{15}$ In consequence, although ABIM has always been apolitical, via Anwar Ibrahim it proved pivotal in reshaping government policy towards Islam, overturning a decades long British-inspired relegation of religion to the private sphere. Indeed, Anwar's Islamisation agenda imprinted itself so firmly onto the previously secular UMNO that commentators began describing the latter as an Islamist organisation. ${ }^{16}$ In short, Mahathir's co-option of Anwar Ibrahim helped mainstream and, ultimately, normalise the politicisation of Islam in Malaysia.

Certainly, by the late 1990s, BN was projecting Islam as the cornerstone of Malaysian identity. ${ }^{17}$ Even Anwar's 1998 expulsion from UMNO (following a spat with Mahathir) was insufficient to destabilise that perspective, which continued into the premierships of Abdullah Badawi (2003-2009) and Najib Razak (2009-2018), even surviving BN's 2018 election defeat to Pakatan Harapan (PH, 'Coalition of Hope') and the subsequent rise of the Perikatan Nasional (PN, 'National Alliance') government under Muhyiddin Yasin (2020). ${ }^{18}$ Moreover, its influence also came to bear on PAS, which suddenly found itself losing control of the Islamist narrative. Over the 1980s, in order to re-assert its authority, in this area PAS began shifting in an ever more conservative direction with the hope of garnering further support among rural Malays. ${ }^{19}$ Simultaneously falling under the control of a new generation of 'ulama' initially led by Yusof Rawa (PAS president 1983-1989), PAS began placing greater emphasis on outward conformity to Islamic (especially legal) norms, including the creation of an Islamic State, now modelled on the Iranian concept of the guardianship of the jurist. ${ }^{20}$ The party also became increasingly combative, notably by turning to takfirism, or the denouncing of Muslim opponents as unbelievers. ${ }^{21}$ Combined with an increased tendency to ignore the concerns of ethnic minorities and refuse cooperation with non-Muslim opposition groups, PAS arguably morphed into a 
considerable source of inter- and intra-communal tension over this period. This has only worsened since the 2015 demise of Nik Abdul Aziz Nik Mat (PAS's Spiritual Leader, 1991-2015, and First Minister of Kelantan, 1990-2013). A moderate figure, Nik Aziz had previously held in check the conservativism of PAS's more extreme 'ulama' leaders, including current president Hadi Awang. After his death, however, Hadi Awang was able to purge PAS of Nik Aziz's legacy, cementing control over party narrative - although this putsch also resulted in the formation of Parti Amanah Negara (AMANAH, 'Nation Trust Party'), a new moderate Islamist voice that continues Nik Aziz's legacy while also taking inspiration from Tunisian politician, Rachid Ghannouchi. ${ }^{22}$ Advocating an inclusive Islamic politics, AMANAH has so far proven popular among urban Malays, even entering the short-lived PH government. How it will shape Malaysian politics long-term, however, is uncertain. ${ }^{23}$

To sum up, Islam has long enjoyed considerable political visibility across the Malay Peninsula. Its integration into modern Malaysian politics, however, resulting in its racialisation, began over the late nineteenth century, with the reform-minded kaum muda. Over the late twentieth century, via Anwar Ibrahim, ABIM's unique version of that form of Islam was co-opted by Mahathir Mohamed, both to undermine PAS and re-assert Malay centrality within the nation. This co-option resulted in a government-led Islamisation drive that continues today; arguably it has served to promote Malay Muslim rights over those of other religious and ethnic groups, while also radicalising PAS ideology. As we shall see, these issues form the backdrop against which our four opponents to Islam's politicisation have emerged. We now turn to a fuller discussion of these figures.

\section{Four Opponents of Islam's Politicisation in Malaysia}

Islam's political resurgence across Malaysia during the 1970s and 1980s inevitably resulted in a proliferation of condemnatory voices. Frequently secular in tone and Western educated, these were directed against the perceived threat increased politicisation of religion posed to civil liberties and inter-communal relations. Today, despite the seemingly entrenched position politicised Islam enjoys in Malaysia, these voices remain prominent across the country's political landscape. Here we profile four of the most significant (living) examples: Chandra Muzaffar, Zainah Anwar, Marina Mahathir, and Siti Kasim. Characterised by prolificacy, high public standing, and a willingness to speak truth to power, these figures stand apart from their peers as significant social influencers capable of attracting largescale media attention, thereby helping to direct the national debate. Here, as a reference point for other scholars, we summarise their social 
and educational backgrounds, principal publications, records of activism, and ideological positions, before attempting to situate their work within a broader intellectual framework. We conclude by suggesting some thoughts on how (or if) they are likely to impact the future direction of Malaysian politics.

\section{Chandra Muzaffar}

Chandra Muzaffar (b. 1947) is an academic and political activist well-known for his staunch independence of mind, prompting some to call him the "conscience" of modern-day Malaysia. Born into a Hindu family from Bedong, Kedah (north Malaysia), he was educated locally, graduating from the National University of Singapore in the late 1960s. First rising to prominence over the 1970s, Chandra has dedicated his life to promoting inter-civilisational dialogue, racial harmony, and inter-religious understanding within the context of Malaysia's broad ethnic mix. In 1977, he founded Aliran Kesedaran Negara (Aliran, 'National Consciousness Stream'), a multi-ethnic reform movement dedicated to achieving social justice in Malaysia, which he headed until 1991. In 1987, after being detained for several months under the now defunct Internal Security Act (ISA) for criticising the first government of Mahathir Mohamed (19812003), he founded the left-leaning NGO, International Movement for a Just World (JUST). Over the 1990s, Chandra developed JUST into an organisation with global reach, establishing branches in seventeen countries, including Australia, New Zealand, the USA, the UK, Sudan, and Iran. ${ }^{26} \mathrm{He}$ continues to head this organisation today. Of our four activists, Chandra alone has attempted to enter politics; from 1999 to 2001 he served as Deputy President of Parti Keadilan Rakyat (PKR, 'People's Justice Party'), established by Anwar Ibrahim after his expulsion from UMNO. ${ }^{27}$ Running in 1999's General Election for the parliamentary seat of Bandar Tun Razak (Kuala Lumpur), Chandra lost to the Malaysian Chinese Association (MCA) candidate representing BN. ${ }^{28}$

A prolific writer, Chandra has published several important books, including: Universalism of Islam (1979), ${ }^{29}$ Islamic Resurgence in Malaysia (1987), ${ }^{30}$ Human Rights and the New World Order (1993), ${ }^{31}$ Alternative Politics for Asia: A Buddhist-Muslim Dialogue (1999), ${ }^{32}$ Muslims, Dialogue, Terror (2003), ${ }^{33}$ Global Ethic or Global Hegemony? (2005), ${ }^{34}$ and Religion and Governance (2009). ${ }^{35}$

Well known for directing his ire towards any section of society, regardless of origin or status, deemed by him to be promoting extreme and divisive views, Chandra has come into conflict with several politically-orientated Islamic groups. Beginning in the 1980s, he became extremely critical of BN's Islamisation drive; mindful of his Indian Hindu heritage, he interpreted this drive as communally 
divisive and designed to favour Malay Muslims over other ethnic and religious groups. ${ }^{36}$ But, despite this initial opposition to Islamisation, which resulted in his 1987 imprisonment, beginning in the 1990s, and in response to the postCold War rise of America as the world's only global hegemonic power, Chandra began producing a series of apologetics defending Islam against accusations of intolerance and political authoritarianism. ${ }^{37}$ Seeking to portray Islam as progressive, democratic, and multicultural, Chandra pivoted towards ABIM and Anwar Ibrahim's call for a creative relationship between modernity and Islam that would allow the latter to blossom in the public sphere. ${ }^{38}$ In more recent years, therefore, Chandra has accepted a role for Islam in public life, but without losing his earlier bite: Chandra continues to criticise traditional Islamic revivalist movements as dogmatically rigid and unsuited to modernity, charging PAS in particular with promoting anachronistic visions of an Islamic state that will only cause communal division. ${ }^{39}$

\section{Zainah Anwar}

Zainah Anwar (b. 1955) is a social activist and prominent Muslim feminist. The daughter of Tan Sri Haji Anwar bin Abdul Malik, an UMNO founding father, she was born and raised in Johor Bahru, the state capital of Johor, where she attended the prestigious (and British-founded) Sultan Ibrahim Girls' School. In 1972, she entered the journalism programme at the Mara Institute of Technology (now Universiti Teknologi Mara, UiTM), based in Shah Alam, Selangor. Subsequently, she worked for the New Straits Times, a leading Englishlanguage Malaysian newspaper owned by UMNO, before leaving Malaysia in 1978 to study journalism at Boston University (US) and then international law and diplomacy at Tufts University (US). Upon completing her studies in 1986, she moved to London, where she worked for the Institute of Strategic and International Studies (1986-1991 and 1994-1999) and the Political Affairs division of the Commonwealth Secretariat. ${ }^{40}$ Zainah is most well-known, however, for co-founding Sisters in Islam (SIS) in 1988. Registered as an NGO in 1993, SIS advocates policy and legal changes designed to safeguard the status of women in society. In addition to her work with this organisation, Zainah has also been a commissioner with Suhakam (Human Rights Commission of Malaysia) and is currently executive director of Musawah, an NGO founded by SIS in 2009 to promote equality and justice within the Muslim family. ${ }^{41}$

Over the span of her career, Zainah has published numerous articles and speeches, including a monthly column in the widely-read Sunday Star newspaper, called 'Sharing the Nation'. In total, she has written three books on political issues and women's rights: Islamic Revivalism in Malaysia: Dakwah 
Among the Students (1987), ${ }^{42}$ Islam and Family Planning (with Rashidah Shuib, 2001), ${ }^{43}$ and Legacy of Honour (2011). ${ }^{44}$ She is also editor of Wanted: Equality and Justice in the Muslim Family (2009). ${ }^{45}$

Taking a human rights-based approach to Islamic reform, Zainah has been inspired by Western feminism to challenge traditional attitudes towards polygamy, child custody, child marriage, hijab, domestic abuse, and other issues affecting women. ${ }^{46}$ In this context, under her leadership SIS actively promoted alternative, female-driven interpretations of the Qur'an; denying that (male) religious scholars have a monopoly over understanding Islamic scripture, SIS has sought to create a space in which women can decide for themselves how to interpret Islam, including shariah. ${ }^{47}$ In this regard, they have been heavily influenced by another of their co-founders, American Muslim convert Amina Wadud, ${ }^{48}$ while demonstrating (perhaps ironically) a similar concern for a return to original sources as seen among fundamentalists.

Since the late 1990s, both Zainah and SIS have vocally criticised BN's Islamisation project, which they causatively link to increased political authoritarianism, attacks on women's rights, and the curbing of civil liberties, including freedom of religion and freedom of expression. ${ }^{49}$ With Zainah at their head, SIS have opposed all attempts to enforce $h u d u d$, a stance that brought them into conflict with PAS and other conservative Islamic groups. PAS, in response, has routinely disparaged Zainah and SIS's religious credentials, accusing them of ignorance and promulgating alien Western values that undermine Malay Muslim culture. In 2014, PAS even persuaded Jabatan Mufti Selangor ('Department of the Mufti of Selangor') to issue a fatwa (legal opinion) condemning SIS as deviant and guilty of promoting "un-Islamic" values (liberalism and religious pluralism).$^{50}$ This fatwa, which would effectively ban SIS in Selangor, was immediately challenged by the movement. Although SIS lost its initial appeal in 2019, as of writing a second remains pending. ${ }^{51}$

\section{Marina Mahathir}

Marina Mahathir (b. 1957) is one of Malaysia's most prominent social activists and the eldest child of Mahathir Mohamed. Born and raised in Alor Setar, the state capital of Kedah, she initially attended the pre-dominantly Chinese St Nicholas convent school, followed by the prestigious Tunku Kurshiah College (TKC), a Malay boarding school in Negeri Sembilan. After a brief period at the Sultan Abdul Hamid College in Alor Setar, she completed her education at the University of Sussex (UK), graduating in 1979 with a degree in international relations. ${ }^{52}$ Since 1980, she has worked in journalism, contributing (from 1989) a regular bi-weekly column called 'Musings' to Malaysia's most widely 
distributed English-language newspaper, The Star (majority owned by MCA, and therefore $\mathrm{BN}$ aligned). ${ }^{53}$ More recently, she has maintained an active online presence through her blog (http://rantingsbymm.blogspot.com) and published three books compiled from her newspaper columns and blogposts: In Liberal Doses (1997), ${ }^{54} 50$ Days: Rantings by MM (2009), ${ }^{55}$ and Telling It Straight (2012). ${ }^{56}$ From 1994 to 2005, Marina also headed Yayasan AIDS Malaysia ('Malaysian AIDS Foundation'). More recently, she has replaced Zainah as the head of SIS. Internationally, she is on the Board of Trustees for the Asian University for Women (Bangladesh). ${ }^{57}$

Throughout her career, Marina has sought to address the points of intersection between Islam, feminism, LGBTQ rights, and race. Although instigated by her father, Marina has consistently opposed Malaysia's Islamisation programme as "Arab colonialism". ${ }^{58}$ Characterising BN's Islamisation drive as a surreptitious attempt to import rigid, Arab-orientated forms of Islam (i.e. Wahhabism) that undermine the traditional Malay Muslim values of tolerance and respect, she has accused BN of causing social division between not just different racial and religious groups, but also between different Muslim communities, where some are judged more "orthodox" than others. ${ }^{59}$ Within this milieu, she has repeatedly cited the treatment of women as a cause for concern; in 2006 she famously likened the status of Malay Muslim women to black South Africans under Apartheid, citing limited educational and employment opportunities. ${ }^{60}$ To help raise awareness of these issues, from 2000 to 2009 Marina co-produced a TV programme called $3 R$ : Respect, Relax and Respond aimed at re-educating Muslim and non-Muslim viewers about the role of women in society. Although occasionally censored, this awarding-winning programme successfully addressed controversial societal issues like female empowerment, domestic violence, and gay rights. Uniquely among Malaysian TV programmes, it has been franchised for non-Muslim audiences in the Philippines and Vietnam. ${ }^{61}$

\section{Siti Kasim}

Our final activist, Siti Kasim (b. 1963), is a lawyer and activist well-known for her flamboyant, unapologetic style and opposition to shariah. Born and raised in Kuala Lumpur, she travelled to London in 1987 to study law at Queen Mary University, eventually becoming a qualified litigation lawyer. Subsequently living and working in London, she returned to Malaysia in 2004, where she became a staunch defender of the country's Orang Asli (indigenous) and LGBTQ communities. Currently, she is co-deputy chair of the Bar Council Committee on Orang Asli Rights. ${ }^{62}$ Although yet to publish, she maintains an active social media presence. 
Overall, Siti is a fierce opponent of Anwar Ibrahim, whose Islamisation agenda (in common with Marina) she interprets as promoting Wahhabism, posited by her as an existential threat to Malaysia's pluralistic society. ${ }^{63}$ Perhaps for this reason, she was consistently critical of the $\mathrm{PH}$ government (which Anwar was set to lead prior to another spat with Mahathir), being particularly vocal in her opposition to its Minister of Religion, AMANAH's Mujahid Yusof Rawa. Dismissing his advocacy of a "compassionate Islam" based on maqasid al-shar 'iah as "useless", she criticised his perceived failure to support liberal groups like SIS as hypocritical and indicative of an anti-liberal agenda. ${ }^{64}$ She was equally scathing of PH's failure to deport controversial Indian preacher, Zakir Naik, despite his inflammatory statements about non-Muslims and women. ${ }^{65}$

Although Siti arguably lacks a detailed, systematic reformist agenda, to date her statements suggest an SIS-orientated vision. For example, in addition to staunchly opposing shariah as inherently discriminatory towards women, she advocates re-interpreting Islamic scripture in tune with liberal feminist ideology; like SIS, for example, she has urged the abolition of hijab based on a re-reading of surah al-Nisa ${ }^{66}$ Siti's real strengths, however, lie in her social activism, in questioning prevailing orthodoxies. In this regard, and within the context of a conservative local culture that prizes modesty, politeness, and respect, her flamboyant and confrontational style has been both her biggest asset and weakness. While guaranteeing her attention, it has often alienated even those sympathetic to her cause. To date, Siti's most prominent forays into activism include her 2016 opposition to an attempt by PAS to extend the jurisdiction of Malaysia's shariah courts, seen by many as a prelude to introducing hudud. During a forum on this issue, she was photographed shouting and "flipping the bird" at PAS supporters. ${ }^{67}$ Again in 2016, Siti was arrested by officers from Jabatan Agama Islam Wilayah Persekutuan (JAWI, 'Department of Islamic Affairs in the Federal Territories') while attending a closed-door transgender event in Kuala Lumpur. JAWI raided this regularly-held event on the grounds that those present were men acting as women, which contravenes shariah. They did not, however, have a correct warrant for the raid; when Siti confronted them about this, she was arrested for obstruction. ${ }^{68}$ Although subsequently acquitted in August 2020, ${ }^{69}$ images of Siti confronting officers at the event, where attendees allegedly "flashed" JAWI officers, shocked many. Most recently, in June 2020, Siti was questioned by both police and the Malaysian Communications and Multimedia Commission (MCMC) regarding a Facebook post condemning PAS for suggesting a temporary ban on the sale and production of alcoholic beverages during an upsurge in drink-driving fatalities. The MCMC reportedly received 114 complaints about the post, prompting its investigation. To date, no charges have been brought. ${ }^{70}$ 
Moving forward, Siti has launched Maju (Malaysian Action for Justice and Unity Foundation), an apolitical NGO aimed at organising Malaysia's moderate, liberal, and progressive voices. ${ }^{71}$ Although yet to significantly influence national politics or policy formation, with Siti at its helm this pressure group has considerable future potential.

As outlined above, PAS and ABIM have both manifested a postcolonial concern with preserving indigenous identity. Within the context of Malaysia's multicultural society, this has entailed appealing to long-standing ethnoreligious associations that have encouraged a blending of Islamist ideology with issues surrounding Malay rights. Unlike Islamist organisations elsewhere in the Muslim world, therefore, PAS and ABIM have found themselves addressing not merely a Muslim audience, but a specifically Malay Muslim audience. In consequence, they have consistently orientated their message around Malay cultural reference points (including use of the Malay language), at the exclusion of other (Muslim and non-Muslim) ethnic and cultural identity markers. Within this context, and perhaps unsurprisingly, the leadership of both PAS and ABIM have tended to share (particularly educational) backgrounds suffuse with traditional Malay cultural values. Both Nik Aziz and Hadi Awang, for example, hailed from traditional rural Malay communities, where they underwent equally traditional Malay-language programmes of religious education later completed in the Middle East at institutions highly respected among Malays (al-Azhar for Nik Aziz; the Islamic University of Medina and al-Azhar for Hadi Awang). ${ }^{72}$ Although Anwar Ibrahim, despite being from rural Penang, attended the secular, Westernised, and English-language Malay College of Kuala Kangsar (MCKK) and then University Malaya (UM), his concern with maintaining Malay social and cultural primacy began early, when he rebelled against the lack of Malay cultural visibility at MCKK. ${ }^{73}$ Subsequently, while majoring in Malay Studies at UM, he also became president of PBMUM, where he devoted his energies to making Malay UM's principal medium of instruction. ${ }^{74}$

Significantly, the largely traditional backgrounds shared by these figures, characterised by rural upbringings, an emphasis on the Malay language, exposure (or a desire to be exposed) to Malay Muslim culture, and subsequent concern with Malay rights, are not replicated to the same degree among our four subjects. Rather, the latter are all products of multicultural urban environments: Chandra was originally a Hindu practitioner from Bedong, a small town just north of the multi-ethnic Sungai Petani (the largest town in Kedah); Zainah grew up in Johor Bahru, with its substantial Chinese population and close proximity to Singapore; Marina grew up in the Kedah state capital, Alor Setar, where she attended a Chinese school; and Siti Kasim is from Kuala Lumpur's urban metropolis. 
Moreover, each received a predominantly English-language education, in three cases taken to tertiary level in the West (UK and US), in the other case in Singapore. Two of our subjects, Zainah and Siti, also spent substantial periods working in the UK. Within this context, it is perhaps unsurprising that all four of our subjects write predominantly in English; although fluent Malay speakers, they have all chosen to express themselves primarily in a non-native, nonMuslim, European language. This also extends to their organisations: JUST, SIS, and Maju all maintain English-language websites with only occasional content in Malay. This has significant implications with regards to intended audience: given the vast majority of rural Malays remain uncomfortable in English, our four subjects do not seem concerned with reaching out to the same target group as PAS, but rather to urban Malays who are generally highly educated and far more likely to speak English. Certainly, SIS's membership, although small, is almost entirely concentrated in the Klang Valley, ${ }^{75}$ in which area all four of our subjects and their organisations operate.

This urban focus immediately invites comparison with ABIM, however, which has similarly tried to attract highly-educated urban Malays, albeit using the Malay language. Indeed, although subsequently parting ways, Chandra was once closely allied to Anwar Ibrahim and PKR, both of which are ABIM aligned, although Zainah, Marina, and (in particular) Siti have all expressed opposition to these organisations. Nevertheless, that all four of our subjects have also sought to democratise the interpretation of Islam by advocating a return to Qur'an and Sunnah, thereby rejecting (or at least downplaying) traditional scholarship, likewise parallels ABIM. But, while ABIM's (re)interpretative strategy has been driven by a Salafi-orientated return to traditional values (piety, modesty, chastity, etc.), all posited as inherently Qur'anic, the four individuals examined here prioritise an interpretative frame based on highly politicised Western discourses. Within the context of women's rights, for example, Zainah, Marina, and Siti have all sought to reinterpret the Qur'an in line with Western notions of female emancipation; stressing individual empowerment and freedom of expression, they advocate relaxing traditional gender and sexual norms, notably by abolishing hijab, encouraging family planning, and increasing levels of female employment. ${ }^{76}$ ABIM (and PAS), on the other hand, have tended to stress the importance of women within the family, emphasising (albeit reconceptualised) traditional values like parenting, modesty, and chastityalthough, it bears saying, without demanding gender segregation, seclusion, or an end to either educational or employment opportunities for women. ${ }^{77}$

As discussed, a desire to preserve and promote Malay rights ultimately underpins Islam's politicisation in Malaysia. In consequence, that politicisation process is arguably both communally driven and parochial, being centred 
on a particular community (the Malays) within a particular national context (Malaysia). Significantly, therefore, our subjects have each taken an explicitly oppositional stance to parochial worldviews, basing themselves instead on (supposedly) universal human rights designed to protect minority groups, not politically dominant majorities like the Malays. ${ }^{78}$ Chandra's sustained opposition to Islamisation amply demonstrates this; he has consistently drawn upon human rights-based discourses to express concern for the social inequalities caused by government-led discrimination favouring the Malay Muslim majority. ${ }^{79}$ Similarly, Marina has highlighted the negative repercussions increased Malay cultural visibility has for the rights of minority groups. She has also emphasised how BN's Islamisation project effectively creates a government sanctioned form of Islam that opposition groups then feel compelled to discredit. As briefly discussed, this has helped radicalise Malaysia's Islamic narrative, encouraging divisive phenomena like takfirism, which is often directed at Muslim minorities. Ultimately, this minority rights focus, also apparent in Siti's championing of Orang Asli and LGBTQ rights, is likely a function of the multicultural backgrounds shared by our four subjects. Hailing from diverse urban environments, they have all spoken about recreating the (perceived) ethnic and religious harmony of their youth by promoting racial and religious equality now. ${ }^{80}$ Given a focus on minorities also characterises Western political discourse, this stance may be a consequence of our subjects' educational and ideological backgrounds, too.

Moving forward, whether our four subjects can influence Malaysia's political landscape over the long-term is uncertain. Although able to boast considerable public visibility, with both Zainah and Marina possessing close familial ties to those in power, their reliance on Western ideological perspectives expressed in English is problematic. As a democracy in which changes of government do occur, Malaysia's political consciousness is shaped by popular appeal as much as by association with powerful elites. The longevity and resilience of Malaysia's Islamisation project, with its celebration of Malay culture (including language), demonstrates this: stretching across governments and between parties, its popularity among everyday Malay voters has made it a perennial feature of the country's political landscape.$^{81}$ In consequence, it is unlikely that the four individuals examined here will be able to significantly influence popular Malay opinion without shifting towards a more Malay Muslim vision. Although their vocal support for issues like freedom of expression, community cohesion, and women's rights will no doubt continue to constitute a valuable check on those in power, particularly within urban contexts, our subjects must seek greater Malay cultural embeddedness or else risk irrelevance. 


\section{Conclusion}

To conclude, since at least the early fifteenth century, Islam has enjoyed varying degrees of political visibility across what is now Malaysia. Beginning in the late nineteenth century, this visibility underwent rapid popular expansion, initially at the hands of reform-minded kaum muda intellectuals, and then in tandem with Islamist organisations like PAS and ABIM. Within Malaysia's late twentieth-century multicultural environment, where a continuation of colonialera economic disparities favouring the Chinese had precipitated sustained Malay Muslim poverty, Islam finally fused with a concern for preserving Malay rights. Appealing to long-standing ethno-religious associations linking a sense of 'Muslimness' with being Malay, idealogues from both PAS and ABIM encouraged a blending of Islamist ideology with broader political issues surrounding Malays. Unlike Islamist organisations elsewhere in the Muslim world, therefore, those in Malaysia found themselves addressing not merely a Muslim audience, but a specifically Malay Muslim audience.

Over the early 1980s, Mahathir Mohamed successfully co-opted this racialised Islamist agenda by bringing Anwar Ibrahim (former ABIM president) into government. This precipitated a nationwide, government-sanctioned Islamisation drive that continues today; stretching across governments and between parties, this drive has promoted Malay Muslim rights over those of other religious and ethnic groups, while simultaneously radicalising broader Islamist discourse. It is against this backdrop that our four opponents to Islam's politicisation emerged. Frequently secular in tone and Western educated, these opponents have directed their ire against the perceived threat increased politicisation of religion poses to civil liberties and inter-communal relations. While the promulgators of politicised Islam generally share traditional backgrounds characterised by rural upbringings, an emphasis on the Malay language, and an exposure to Malay Muslim culture, our four subjects are more cosmopolitan. Products of multicultural urban environments, they were educated abroad in English-language settings, continue to use English in preference to Malay, and demonstrate a preoccupation with upholding not Malay Muslim culture but (supposedly) universal human rights rooted in Western discourse. While PAS, ABIM, and other relevant actors have therefore taken pains to portray themselves as champions of Malay culture, consistently appealing to Malay identity markers and using the Malay language, their opponents take up a position centred on Western concepts expressed in English. 
Despite the seemingly entrenched position politicised Islam now enjoys in Malaysia, our four subjects remain prominent within the country's political landscape. Their prolificacy, high public standing, and willingness to speak truth to power have ensured they remain significant social influencers. The longevity and resilience of Malaysia's Islamisation project, however, based in its appeal to Malay Muslim values, suggests our opponents will not be able to significantly influence popular Malay opinion without shifting towards a more Malay Muslim vision. They must seek greater Malay cultural embeddedness or else risk irrelevance.

\section{Notes}

* Alexander Wain, Associate Research Fellow, International Institute of Advanced Islamic Studies (IAIS) Malaysia. Email: alex@iais.org.my.

1. A. C. Milner, 'Islam and Malay Kingship,' Journal of the Royal Asiatic Society of Great Britain and Northern Ireland 1 (1981): 46-70; Alan Strathern, 'Global Patterns of Ruler Conversion to Islam and the Logic of Empirical Religiosity,' in Islamisation: Comparative Perspectives from History, ed. A. C. S. Peacock (Edinburgh: Edinburgh University Press, 2017), 37-8.

2. Carool Kersten, A History of Islam in Indonesia: Unity in Diversity (Edinburgh: Edinburgh University Press, 2017), 56-64.

3. Michael Laffan, 'The Tangled Roots of Islamist Activism in Southeast Asia,' Cambridge Review of International Affairs 16, no. 3 (2003): 403-5.

4. Joseph Chinyong Liow, Piety and Politics: Islamism in Contemporary Malaysia (Oxford: Oxford University Press, 2009), 19.

5. Taken from Malaysia's 2010 census, see Taburan Penduduk dan Ciri-Ciri Asas Demografi (n.p.: Jabatan Perangkaan Malaysia, 2011), 5, 9.

6. For a far more detailed overview of how this politico-ethno-religious interconnection formed over the late colonial period, see William R. Roff, The Origins of Malay Nationalism (New Haven: Yale University Press, 1967).

7. Originally known as Persatuan Islam Se-Tanah Malaya (PMIA, 'Pan-Malayan Islamic Association'), PAS was founded by disaffected 'ulama' from the United Malays National Organisation (UMNO) who objected to the latter's accommodative stance towards non-Malays and apparent indifference towards Islam, see John L. Esposito and John O. Voll, Islam and Democracy (Oxford: Oxford University Press, 1996), 133. A participant in every election since 1955, the party currently holds 18 of the Federal Legislature's 222 seats, making it Malaysia's largest Islamist party, see 'Statistik Dewan Rakyat,' Parlimen Malaysia. Available at: https://www.parlimen.gov.my/statistik.html?uweb=dr\& (Accessed on: 26 March 2021). Although historically PAS has been Malaysia's leading opposition party, it has entered Federal Government twice: from 1974 to 1977 in coalition with UMNO and from 2020 onwards as part of the Perikatan 
Nasional (PN, 'National Alliance') government. PAS is also noteworthy for being the first non-BN political party to gain control of State Legislatures, including in Kelantan (1959-1977 and 1990-present), Terengganu (1959-1962, 19992004 and 2018-present), and Kedah (2008-2013, 2020-present). In coalition with other parties, it has also ruled Perak (2008-2009, 2020-present) and Johor (2020-present), see 'Sejarah Parti Islam Se Malaysia (PAS),' Parti Islam Se Malaysia. Available at: https://pas.org.my/sejarah-parti-islam-se-malaysia-pas/ (Accessed on: 19 April 2021). The distribution of these legislatures reflects the party's traditional support base, which lies in the Peninsula's conservative rural north, notably the states of Kelantan and Terengganu.

8. Farish A. Noor, The Malaysian Islamic Party 1951-2013: Islamism in a Mottled Nation (Amsterdam: Amsterdam University Press, 2014), 67; John Funston, Malay Politics in Malaysia: A Study of UMNO and PAS (Singapore: Heinemann Educational Books, 1980), 94.

9. M. Kamal Hassan, 'The Influence of Mawdudi's Thought on Muslims in Southeast Asia: A Brief Survey,' Muslim World 93, no. 3 (2003): 429-64.

10. Liow, Piety and Politics, 115-7. Although arguably Malaysia's most well-known Islamist organisation, ABIM has never contested an election, being officially apolitical. It did, however, openly campaign for PAS during the 1978 General Election. Two PAS presidents, Fadzil Noor (in office 1989-2002) and Hadi Awang (2002-), are also former ABIM members.

11. Quoted in Zainah Anwar, Islamic Revivalism in Malaysia: Dakwah Among the Students (Petaling Jaya: Pelanduk Publications, 1987), 11.

12. Quoted in Charles Allers, Anwar Ibrahim: Evolution of a Muslim Democrat (Singapore: Monsoon Books, 2014), 43.

13. Liow, Piety and Politics, 116.

14. Peter G. Riddell, Islam and the Malay-Indonesian World: Transmission and Responses (Honolulu: University of Hawai'i Press, 2001), 242.

15. Ibid.

16. Meredith L. Weiss, 'The Changing Shape of Islamic Politics in Malaysia,' Journal of East Asian Studies 4 (2004): 153-7.

17. Virginia Matheson Hooker, 'Reconfiguring Malay and Islam in Contemporary Malaysia,' in Contesting Malayness: Malay Identity Across Boundaries, ed. Timothy P. Barnard (Singapore: Singapore University Press, 2006), 152.

18. Liow, Piety and Politics, 116-7.

19. Ibid, 33-5; Judith Nagata, 'Religious Ideology and Social Change: The Islamic Revival in Malaysia,' Pacific Affairs 53, no. 3 (1980): 412-3. This lurch towards Islamist 'orthodoxy' was facilitated by Malaysian university students who, while living in Great Britain over the 1970s, gained exposure to Ikhwani and Jamaat-e ideology via two Malaysian student associations: Saura Islam ('Voice of Islam') and the Islamic Representative Council (IRC). Upon returning to Malaysia, these students joined PAS, infusing it with a 'purer' Islamic vision, see Esposito and Voll, Islam and Democracy, 134-6.

20. Although obscured behind references to "parliamentary shura" (where shura is best left to jurists), Iran's 'guardianship of the jurist' underpins the final $2003 \mathrm{draft}$ of PAS's blueprint for an Islamic State, see PAS, The Islamic State Document (Bandar Bangi Baru: Brotsis Info System, 2003), 24-5. Since 1987, the concept 
has also been incorporated into PAS's party structure via a 15-member strong Majlis Shura Ulama (' 'Ulama' Consultative Council'). Reminiscent of Iran's Guardian Council, this Majlis is led by a musyidul 'am ('spiritual leader') and vets all PAS activities and pronouncements to ensure they conform to shariah, see Liow, Piety and Politics, 36.

21. Riddell, Malay-Indonesian World, 228-9; Liow, Piety and Politics, 37-9. Current PAS president, Hadi Awang, has long advocated takfirism: in a notorious speech called Amanat Haji Hadi ('Haji Hadi's Edict', delivered 7 April 1981 at Banggol Peradong, Terengganu), Hadi labelled all UMNO supporters kafir (unbelievers) while simultaneously declaring that any PAS supporter who died opposing them would die a martyr. In traditional Islam, to takfir a practicing, sane Muslim is considered haram (forbidden), see Abdullah Saeed and Hassan Saeed, Freedom of Religion, Apostasy and Islam (London: Routledge, 2016), 51ff.

22. Maszlee Malik, 'From Political Islam to Democrat Muslim: A Case Study of Rashid Ghannouchi's Influence on ABIM, IKRAM, AMANAH and DAP,' Intellectual Discourse 25, no. 1 (2017): 37-40.

23. Maszlee Malik, 'Rethinking the Role of Islam in Malaysian Politics: A Case Study of Parti Amanah Negara (AMANAH),' Islam and Civilisational Renewal 8, no. 4 (2017): 458. At the time of writing, AMANAH has 11 seats in the Federal Legislature. It was the third largest party in $\mathrm{PH}$, under whom its president, Mohamad Sabu, served as Minister of Defence, see 'Statistik Dewan Rakyat.'

24. Riddell, Malay-Indonesian World, 258.

25. 'Muzaffar, Chandra,' in The Oxford Dictionary of Islam, ed. John L. Esposito. Available at: http://www.oxfordislamicstudies.com/article/opr/t125/e1673. (Accessed on: 22 March 2021).

26. Ibid; Riddell, Malay-Indonesian World, 255.

27. For a brief history of PKR, see 'Sejarah Parti,' Keadilan Rakyat. Available at: https://keadilanrakyat.org/index.php/info-parti/sejarah-parti/. (Accessed on: 22 March 2021).

28. 'Keputusan Pilihan Raya Umum Parlimen Negeri W.P. Kuala Lumpur bagi Tahun 1999,' Suruhanjaya Pilihan Raya Malaysia. Available at: http://semak. spr.gov.my/spr/laporan/5 KedudukanAkhir.php. (Accessed on: 22 March 2021).

29. Chandra Muzaffar, The Universalism of Islam (Penang: Aliran, 1979).

30. Chandra Muzaffar, Islamic Resurgence in Malaysia (Petaling Jaya: Fajar Bakti, 1987).

31. Chandra Muzaffar, Human Rights and the New World Order (Penang: JUST, 1993).

32. Chandra Muzaffar, Alternative Politics for Asia: A Buddhist-Muslim Dialogue (Petaling Jaya: JUST, 1999).

33. Chandra Muzaffar, Muslims, Dialogue, Terror (Petaling Jaya: JUST, 2003).

34. Chandra Muzaffar, Global Ethic or Global Hegemony? Reflections on Religion, Human Dignity and Civilisational Interaction (London: ASEAN Academic Press, 2005).

35. Chandra Muzaffar, Religion and Governance (Shah Alam: Arah Pendidikan, 2009).

36. Muzaffar, Islamic Resurgence, 87-9.

37. See Muzafar, Alternative Politics; Chandra Muzaffar, 'Universalism in Islam,' 
in Liberal Islam: A Sourcebook, ed. C. Kurzman (Oxford: Oxford University Press, 1998), 155-60.

38. Muzaffar, Islamic Resurgence.

39. Ibid, 74-8.

40. 'Anwar, Zainah,' in The Oxford Encyclopaedia of Islam and Women, ed. Natana J. DeLong-Bas. Available at: https:/www.oxfordreference.com/ view/10.1093/acref:oiso/9780199764464.001.0001/acref-9780199764464-e0086?rskey=VGgSmE\&result=20. (Accessed on: 20 March 2021); K. S. Nathan and Mohammad Hashim Kamali, ed., Islam in Southeast Asia: Political, Social and Strategic Challenges for the $21^{\text {st }}$ Century (Singapore: Institute of Southeast Asian Studies, 2005), 357.

41. See their website, https://www.musawah.org/. (Accessed on: 24 March 2021).

42. Anwar, Islamic Revivalism.

43. Zainah Anwar and Rashidah Shuib, Islam and Family Planning (Kuala Lumpur: Sisters in Islam, 2001). Translated into Malay as Islam dan Perancangan Keluarga, this text has proven popular; second and third editions were published in 2002 and 2008 respectively, in cooperation with Persatuan Perancangan Keluarga Kelantan ('Kelantan Family Planning Association').

44. Zainah Anwar, Legacy and Honour (Kuala Lumpur: Yayasan Mohamed Noah, 2011).

45. Zainah Anwar, ed., Wanted: Equality and Justice in the Muslim Family (Petaling Jaya: Musawah, 2009).

46. Liow, Piety and Politics, 124.

47. 'Who we Are,' Sisters in Islam. Available at: https://sistersinislam.org/who-weare/. (Accessed on: 12 February 2021).

48. Between 1989 and 1992, Wadud was Assistant Professor at the International Islamic University of Malaysia (IIUM), where she helped establish SIS. Her work remains central to SIS's approach to Islamic scripture, see especially Amina Wadud, Qur'an and Woman: Re-reading the Sacred Text from a Woman's Perspective (New York: Oxford University Press, 1999).

49. Zainah Anwar, 'Law-making in the Name of Islam: Implications for Democratic Governance,' in Islam in Southeast Asia: Political, Social and Strategic Challenges for the 21st Century, ed. K. S. Nathan and Mohammad Hashim Kamali (Singapore: Institute of Southeast Asian Studies, 2005), 126-7.

50. 'PAS Youth: Sisters in Islam "Insolent", "Extremists" for contesting Fatwa,' Malay Mail, 31 October 2014. Available at: https:/www.malaymail.com/ news/malaysia/2014/10/31/pas-youth-sisters-in-islam-insolent-extremists-forcontesting-fatwa/773853. (Accessed on: 23 March 2021).

51. 'A Dark Day for Malaysia - Sisters in Islam,' Malay Mail, 27 August 2019. Available at: https:/www.malaymail.com/news/what-you-think/2019/08/27/adark-day-for-malaysia-sisters-in-islam/1784806. (Accessed on: 23 March 2021); Ainaa Aiman, 'Selangor Fatwa on SIS Temporarily Suspended Pending Appeal,' Free Malaysia Today, 23 January 2020. Available at: https:/www. freemalaysiatoday.com/category/nation/2020/01/23/selangor-fatwa-on-sistemporarily-suspended-pending-appeal/. (Accessed on: 23 March 2021).

52. Shanon Shah, 'Liberal, Muslim, Feminist, and Comfortable,' The Nut Graph. Available at: https://www.thenutgraph.com/liberal-muslim- 
feminist-and-comfortable/. (Accessed on: 12 February 2021); 'Biodata Datin Paduka Marina Mahathir.' Available at: https://static1.squarespace. $\mathrm{com} / \mathrm{static} / 55371 \mathrm{ac} 3 \mathrm{e} 4 \mathrm{~b} 08 \mathrm{f} 12059 \mathrm{e} 3112 / \mathrm{t} / 55714 \mathrm{affe} 4 \mathrm{~b} 028 \mathrm{f0} 24207 \mathrm{~d}$ ec/1433488127047/BIODATA+Datin+Paduka+Marina+Mahathir.pdf. (Accessed on: 12 February 2021).

53. Murray Hiebert, Under Beijing's Shadow: Southeast Asia's China Challenge (Washington, DC: Center for Strategic and International Studies, 2020), 366.

54. Marina Mahathir, In Liberal Doses (Petaling Jaya: Star Publications, 1997). Published same year in Singapore by Archipelago Press, republished 2012 by Editions Didier Millet to coincide with launch of Telling It Straight.

55. Marina Mahathir, 50 Days: Rantings by MM (Petaling Jaya: ZI Publications, 2009).

56. Marina Mahathir, Telling It Straight (Singapore: Editions Didier Millet, 2012).

57. 'Biodata Datin Paduka Marina Mahathir.'

58. Boo Su-Lyn, 'Marina Mahathir: Malaysia Undergoing "Arab Colonialism,", Malay Mail, 23 May 2015. Available at: https://www.malaymail.com/ news/malaysia/2015/05/23/marina-mahathir-malaysia-undergoing-arabcolonialism/902417. (Accessed on: 24 March 2021).

59. 'Islamisation will tear Malaysia apart, says Marina Mahathir,' Today, 18 January 2018. Available at: https://www.todayonline.com/world/islamisation-will-tearmalaysia-apart-says-marina-mahathir. (Accessed on: 24 March 2021).

60. Jonathan Kent, 'Malaysia “Apartheid” Row Deepens,' $B B C$ News, 11 March 2006. Available at: http://news.bbc.co.uk/2/hi/asia-pacific/4795808.stm. (Accessed on: 24 March 2021).

61. Marina Mahathir, 'How 3R Changed Malaysian TV,' The Nut Graph, 27 April 2010. Available at: https://thenutgraph.com/how-3r-changed-msian-tv/. (Accessed on: 12 February 2021).

62. Boo Su-Lyn, '10 Things About: Siti Kasim, Lawyer and Activist,' Malay Mail, 25 September 2016. Available at: https:/www.malaymail.com/news/ malaysia/2016/09/25/10-things-about-siti-kasim-lawyer-and-activist/1213363. (Accessed on: 15 March 2021).

63. Ibid.

64. Siti Kasim, 'Mujahid is a Big Fat Zero,' Malaysia Today, 16 November 2019. Available at: https:/www.malaysia-today.net/2019/11/16/mujahid-is-a-big-fatzero/. (Accessed on: 15 March 2021).

65. Vinodh Pillai, 'Nonsense, says Siti Kasim on Dr M's Refusal to Hand Over Zakir Naik,' Free Malaysia Today, 11 June 2019. Available at: https://www. freemalaysiatoday.com/category/nation/2019/06/11/nonsense-says-siti-kasimon-dr-ms-refusal-to-hand-over-zakir-naik/. (Accessed on: 24 March 2021).

66. Boo, '10 Things.'

67. Boo Su-Lyn, 'Sometimes you have to Shout,' Malay Mail, 16 September 2016. Available at: https://www.malaymail.com/news/opinion/2016/09/16/sometimesyou-have-to-shout/1206857. (Accessed on: 24 March 2021).

68. 'Siti Kasim Faces Charges a Year after Raid on Transgender Fundraising Event,' Frontline Defenders, 20 June 2017. Available at: https://www.frontlinedefenders. org/en/case/siti-kasim-faces-charges-year-after-raid-transgender-fundraisingevent. (Accessed on: 24 March 2021). 
69. 'Siti Kasim Acquitted of Obstructing Jawi Officer at Transgender Event,' The Star, 21 August 2021. Available at: https://www.thestar.com.my/news/ nation/2020/08/21/siti-kasim-acquitted-of-obstructing-jawi-officer-attransgender-event. (Accessed on: 15 March 2021).

70. G. Prakash, 'Lawyer Siti Kasim Quizzed by MCMC over Facebook Posting about PAS, Tahfiz,' Malay Mail, 18 June 2020. Available at: https://www.malaymail. $\mathrm{com} /$ news/malaysia/2020/06/18/lawyer-siti-kasim-quizzed-by-mcmc-overfacebook-posting-about-pas-tahfiz/1876624. (Accessed on: 24 March 2021).

71. See their website, https://mymaju.org/. (Accessed on: 24 March 2021).

72. Riddell, Malay-Indonesian World, 224, 227.

73. Allers, Anwar, 41-2.

74. Ibid, 39, 43ff; Farish Noor, 'The Localization of Islamist Discourse in the Tafsir of Tuan Guru Nik Aziz Nik Mat, Murshid'ul Am of PAS,' in Malaysia: Islam, Society and Politics, ed. Virginia Hooker and Norani Othman (Singapore: Institute of Southeast Asian Studies, 2003), 226.

75. Liow, Piety and Politics, 124.

76. Anwar and Shuib, Islam and Family Planning; Boo, '10 Things.'

77. Aihwa Ong, 'State versus Islam: Malay Families, Women's Bodies, and the Body Politic in Malaysia,' American Ethnologist 17, no. 2 (1990): 269. ABIM's commitment to promoting prominent public roles for women continues into the present, see Haziqah Jasmani, 'ABIM: K'jaan perlu pandang serius penyingkiran wanita berwibawa dalam GLC,' Malaysiakini, 10 April 2020. Available at: https://www.malaysiakini.com/news/519986. (Accessed on: 24 May 2021).

78. Al Khanif, Religious Minorities, Islam and the Law: International Human Rights and Islamic Law in Indonesia (London: Routledge, 2021), ch. 2.

79. Muzaffar, Islamic Resurgence, 87-9.

80. For example, see 'Islamisation will tear Malaysia apart'; Boo, '10 Things.'

81. Certainly, it remains a contentious issue, even after the most recent general election, see Tasnim Lokman, Manirajan Ramasamy, and Nurhayati Abdullah, 'Anwar Raises Concern over Welfare and Rights of the Malays,' New Straits Times, 30 August 2018. Available at: https://www.nst.com.my/news/ nation/2018/08/406531/anwar-raises-concern-over-welfare-and-rights-malays. (Accessed on: 24 May 2021); Nicholas Chung, 'Malays not Confident Anwar can Champion their Rights, says Analyst,' Free Malaysia Today, 7 January 2020. Available at: https://www.freemalaysiatoday.com/category/nation/2020/01/07/ malays-not-confident-anwar-can-champion-their-rights-says-analyst/. (Accessed on: 24 May 2021).

\section{Bibliography}

'A Dark Day for Malaysia - Sisters in Islam.' Malay Mail, 27 August 2019. Available at: https:/www.malaymail.com/news/what-you-think/2019/08/27/a-dark-dayfor-malaysia-sisters-in-islam/1784806.

Aiman, Ainaa. 'Selangor Fatwa on SIS Temporarily Suspended Pending Appeal.' Free Malaysia Today, 23 January 2020. Available at: https://www.freemalaysiatoday. 
com/category/nation/2020/01/23/selangor-fatwa-on-sis-temporarily-suspendedpending-appeal/.

Allers, Charles. Anwar Ibrahim: Evolution of a Muslim Democrat. Singapore: Monsoon Books, 2014.

'Anwar, Zainah.' In The Oxford Encyclopaedia of Islam and Women, edited by Natana J. DeLong-Bas. Available at: https://www.oxfordreference.com/ view/10.1093/acref:oiso/9780199764464.001.0001/acref-9780199764464-e0086? $\mathrm{rskey}=\mathrm{VGgSmE} \&$ result $=20$.

Anwar, Zainah. Islamic Revivalism in Malaysia: Dakwah Among the Students. Petaling Jaya: Pelanduk Publications, 1987.

'Law-making in the Name of Islam: Implications for Democratic Governance.' In Islam in Southeast Asia: Political, Social and Strategic Challenges for the $21^{\text {st }}$ Century, edited by K. S. Nathan and Mohammad Hashim Kamali, 121-134. Singapore: Institute of Southeast Asian Studies, 2005.

Jaya: Musawah, 2009.

Legacy and Honour. Kuala Lumpur: Yayasan Mohamed Noah, 2011.

Anwar, Zainah, and Rashidah Shuib. Islam and Family Planning. Kuala Lumpur: Sisters in Islam, 2001.

'Biodata Datin Paduka Marina Mahathir.' Squarespace.com. Available at: https:// static1.squarespace.com/static/55371ac3e4b08f12059e3112/t/55714affe4b028f 024207dec/1433488127047/BIODATA+Datin+Paduka+Marina+Mahathir.pdf.

Boo Su-Lyn. 'Marina Mahathir: Malaysia Undergoing "Arab Colonialism." Malay Mail, 23 May 2015. Available at: https://www.malaymail.com/ news/malaysia/2015/05/23/marina-mahathir-malaysia-undergoing-arabcolonialism/902417.

'Sometimes you have to Shout.' Malay Mail, 16 September 2016. Available at: https://www.malaymail.com/news/opinion/2016/09/16/sometimesyou-have-to-shout/1206857.

. '10 Things About: Siti Kasim, Lawyer and Activist.' Malay Mail, 25 September 2016. Available at: https://www.malaymail.com/news/ malaysia/2016/09/25/10-things-about-siti-kasim-lawyer-and-activist/1213363.

Chung, Nicholas. 'Malays not Confident Anwar can Champion their Rights, says Analyst.' Free Malaysia Today, 7 January 2020. Available at: https://www. freemalaysiatoday.com/category/nation/2020/01/07/malays-not-confidentanwar-can-champion-their-rights-says-analyst/.

Esposito, John L., and John O. Voll. Islam and Democracy. Oxford: Oxford University Press, 1996.

Funston, John. Malay Politics in Malaysia: A Study of UMNO and PAS. Singapore: Heinemann Educational Books, 1980. 
Hassan, M. Kamal. 'The Influence of Mawdudi's Thought on Muslims in Southeast Asia: A Brief Survey.' Muslim World 93, no. 3 (2003): 429-64.

Hiebert, Murray. Under Beijing's Shadow: Southeast Asia's China Challenge. Washington, DC: Center for Strategic and International Studies, 2020.

'Islamisation will tear Malaysia apart, says Marina Mahathir.' Today, 18 January 2018. Available at: https://www.todayonline.com/world/islamisation-will-tearmalaysia-apart-says-marina-mahathir.

Jasmani, Haziqah. 'ABIM: K'jaan perlu pandang serius penyingkiran wanita berwibawa dalam GLC.' Malaysiakini, 10 April 2020. Available at: https://www. malaysiakini.com/news/519986.

Kasim, Siti. 'Mujahid is a Big Fat Zero.' Malaysia Today, 16 November 2019. Available at: https://www.malaysia-today.net/2019/11/16/mujahid-is-a-big-fatzero/.

Kent, Jonathan. 'Malaysia “Apartheid” Row Deepens.' BBC News, 11 March 2006. Available at: http://news.bbc.co.uk/2/hi/asia-pacific/4795808.stm.

'Keputusan Pilihan Raya Umum Parlimen Negeri W.P. Kuala Lumpur bagi Tahun 1999.' Suruhanjaya Pilihan Raya Malaysia. Available at: http://semak.spr.gov. my/spr/laporan/5_KedudukanAkhir.php.

Kersten, Carool. A History of Islam in Indonesia: Unity in Diversity. Edinburgh: Edinburgh University Press, 2017.

Khanif, Al. Religious Minorities, Islam and the Law: International Human Rights and Islamic Law in Indonesia. London: Routledge, 2021.

Laffan, Michael. 'The Tangled Roots of Islamist Activism in Southeast Asia.' Cambridge Review of International Affairs 16, no. 3 (2003): 397-414.

Liow, Joseph Chinyong. Piety and Politics: Islamism in Contemporary Malaysia. Oxford: Oxford University Press, 2009.

Lokman, Tasnim, Manirajan Ramasamy, and Nurhayati Abdullah. 'Anwar Raises Concern over Welfare and Rights of the Malays.' New Straits Times, 30 August 2018. Available at: https://www.nst.com.my/news/nation/2018/08/406531/ anwar-raises-concern-over-welfare-and-rights-malays.

Mahathir, Marina. In Liberal Doses. Petaling Jaya: Star Publications, 1997. 50 Days: Rantings by MM. Petaling Jaya: ZI Publications, 2009.

'How 3R Changed Malaysian TV.' The Nut Graph, 27 April 2010. Available at: https://thenutgraph.com/how-3r-changed-msian-tv/.

Telling It Straight. Singapore: Editions Didier Millet, 2012.

Malik, Maszlee. 'From Political Islam to Democrat Muslim: A Case Study of Rashid Ghannouchi's Influence on ABIM, IKRAM, AMANAH and DAP.' Intellectual Discourse 25, no. 1 (2017): 21-53. 
- 'Rethinking the Role of Islam in Malaysian Politics: A Case Study of Parti Amanah Negara (AMANAH).' Islam and Civilisational Renewal 8, no. 4 (2017): 457-472.

Matheson Hooker, Virginia. 'Reconfiguring Malay and Islam in Contemporary Malaysia.' In Contesting Malayness: Malay Identity Across Boundaries, edited by Timothy P. Barnard,149-167. Singapore: Singapore University Press, 2006.

Milner, A. C. 'Islam and Malay Kingship.' Journal of the Royal Asiatic Society of Great Britain and Northern Ireland 1 (1981): 46-70.

'Muzaffar, Chandra.' In The Oxford Dictionary of Islam, edited by John L. Esposito. Available at: http://www.oxfordislamicstudies.com/article/opr/t125/e1673.

Muzaffar, Chandra. The Universalism of Islam. Penang: Aliran, 1979.

. Islamic Resurgence in Malaysia. Petaling Jaya: Fajar Bakti, 1987.

- Human Rights and the New World Order. Penang: JUST, 1993.

-. 'Universalism in Islam.' In Liberal Islam: A Sourcebook, edited by

C. Kurzman, 155-160. Oxford: Oxford University Press, 1998.

Jaya: JUST, 1999.

. Alternative Politics for Asia: A Buddhist-Muslim Dialogue. Petaling . Muslims, Dialogue, Terror. Petaling Jaya: JUST, 2003.

. Global Ethic or Global Hegemony? Reflections on Religion, Human Dignity and Civilisational Interaction. London: ASEAN Academic Press, 2005.

Religion and Governance. Shah Alam: Arah Pendidikan, 2009.

Nagata, Judith. 'Religious Ideology and Social Change: The Islamic Revival in Malaysia.' Pacific Affairs 53, no. 3 (1980): 405-439.

Nathan, K. S., and Mohammad Hashim Kamali, ed. Islam in Southeast Asia: Political, Social and Strategic Challenges for the $21^{\text {st }}$ Century. Singapore: Institute of Southeast Asian Studies, 2005.

Noor, Farish A. 'The Localization of Islamist Discourse in the Tafsir of Tuan Guru Nik Aziz Nik Mat, Murshid'ul Am of PAS.' In Malaysia: Islam, Society and Politics, edited by Virginia Hooker and Norani Othman, 195-235. Singapore: Institute of Southeast Asian Studies, 2003.

Nation. Amsterdam: Amsterdam University Press, 2014.

Ong, Aihwa. 'State versus Islam: Malay Families, Women's Bodies, and the Body

Politic in Malaysia.' American Ethnologist 17, no. 2 (1990): 258-276.

PAS (Parti Islam Se-Malaysia). The Islamic State Document. Bandar Baru Bangi: Brotsis Info System, 2003.

'PAS Youth: Sisters in Islam "Insolent", "Extremists" for contesting Fatwa.' 
Malay Mail, 31 October 2014. Available at: https://www.malaymail.com/ news/malaysia/2014/10/31/pas-youth-sisters-in-islam-insolent-extremists-forcontesting-fatwa/773853.

Pillai, Vinodh. 'Nonsense, says Siti Kasim on Dr M's Refusal to Hand Over Zakir Naik.' Free Malaysia Today, 11 June 2019. Available at: https://www. freemalaysiatoday.com/category/nation/2019/06/11/nonsense-says-siti-kasimon-dr-ms-refusal-to-hand-over-zakir-naik/.

Prakash, G. 'Lawyer Siti Kasim Quizzed by MCMC over Facebook Posting about PAS, Tahfiz.' Malay Mail, 18 June 2020. Available at: https://www.malaymail. com/news/malaysia/2020/06/18/lawyer-siti-kasim-quizzed-by-mcmc-overfacebook-posting-about-pas-tahfiz/1876624.

Riddell, Peter G. Islam and the Malay-Indonesian World: Transmission and Responses. Honolulu: University of Hawai'i Press, 2001.

Roff, William R. The Origins of Malay Nationalism. New Haven: Yale University Press, 1967.

Saeed, Abdullah, and Hassan Saeed. Freedom of Religion, Apostasy and Islam. London: Routledge, 2016.

'Sejarah Parti.' Keadilan Rakyat. Available at: https://keadilanrakyat.org/index.php/ info-parti/sejarah-parti/.

'Sejarah Parti Islam Se Malaysia (PAS).' Parti Islam Se Malaysia. Available at: https://pas.org.my/sejarah-parti-islam-se-malaysia-pas/.

Shah, Shanon. 'Liberal, Muslim, Feminist, and Comfortable.' The Nut Graph. Available at: https://www.thenutgraph.com/liberal-muslim-feminist-andcomfortable/.

'Siti Kasim Acquitted of Obstructing Jawi Officer at Transgender Event.' The Star, 21 August 2021. Available at: https://www.thestar.com.my/news/nation/2020/08/21/ siti-kasim-acquitted-of-obstructing-jawi-officer-at-transgender-event.

'Siti Kasim Faces Charges a Year after Raid on Transgender Fundraising Event.' Frontline Defenders, 20 June 2017. Available at: https://www.frontlinedefenders. org/en/case/siti-kasim-faces-charges-year-after-raid-transgender-fundraisingevent.

'Statistik Dewan Rakyat.' Parlimen Malaysia. Available at: https://www.parlimen. gov.my/statistik.html?uweb=dr\&.

Strathern, Alan. 'Global Patterns of Ruler Conversion to Islam and the Logic of Empirical Religiosity.' In Islamisation: Comparative Perspectives from History, edited by A. C. S. Peacock, 21-55. Edinburgh: Edinburgh University Press, 2017.

Taburan Penduduk dan Ciri-Ciri Asas Demografi. n.p.: Jabatan Perangkaan Malaysia, 2011. 
Wadud, Amina. Qur'an and Woman: Re-reading the Sacred Text from a Woman's Perspective. New York: Oxford University Press, 1999.

Weiss, Meredith L. 'The Changing Shape of Islamic Politics in Malaysia.' Journal of East Asian Studies 4 (2004): 139-173.

'Who we Are.' Sisters in Islam. Available at: https://sistersinislam.org/who-we-are/. 